Original Paper http://ajol.info/index.php/ijbcs http://indexmedicus.afro.who.int

\title{
Enhancement of proline content and antioxidant enzyme activities induced by drought stress in maize (Zea mays L.) by application of compost
}

\author{
Atalaèsso BOKOBANA ${ }^{1,2^{*}}$, Outendé TOUNDOU ${ }^{1,2}, \mathrm{Komi} \mathrm{ODAH}^{2}$, \\ Koffi S. S. DOSSOU ${ }^{1,2}$ and Koffi TOZO ${ }^{1,2}$ \\ ${ }^{1}$ Laboratory of Management, Treatment and Valorisation of Waste, University of Lomé, \\ 01 BP 1515, Lomé 01, Togo. \\ ${ }^{2}$ Laboratory of Plant Biotechnology and Physiology, University of Lomé, \\ 01 BP 1515, Lomé 01, Togo. \\ *Corresponding author; E-mail: bokoba3@yahoo.fr; Tel: (00228) 90386179
}

\begin{abstract}
In sub-Saharan Africa, soil degradation and recurrent droughts are major obstacles to a sustainable agriculture. This study aimed at investigating the effect of compost addition to soil on proline content and activities of the antioxidant enzymes [catalase (CAT), ascorbate peroxidase (APX)] in maize plants, under drought stress conditions. The test was carried out in $20 \mathrm{~L}$ plastic pots containing either sandy soil or sandy soil with the fertilizer, under natural conditions. The water deficit was induced at male blooming and milky grain stages. Plant irrigation was done by successive weighing of the pots during which the control is reduced to the same weight corresponding to $70 \%$ of the useful water reserve (UWR), while the stressed treatment maintains the water content at $30 \%$ of the UWR for 10 days. At the end of the stress period, the proline content, the CAT and APX activities in the leaves were determined through a spectrophotometry. The results show an important accumulation of proline and increase in enzymatic activity induced by water deficit in plants grown on compost $(\mathrm{p}=0.00000$ at $\mathrm{p}<0.05)$. This study provides evidence for a beneficial effect of compost application in enhancing drought tolerance of maize.
\end{abstract}

(C) 2019 International Formulae Group. All rights reserved

Keywords: Drought stress; compost; proline; antioxidant enzymes; Zea mays L.

\section{INTRODUCTION}

In recent decades, Togo has experienced serious deregulation of the rainfall, such as long-term droughts or floods at unexpected periods (Adewi et al., 2010; Lemou, 2008). Zones of drought appear during cultural cycles. From 1961 to 2010, great thermic increases have been registered in the southern and northern plains (respectively from 1,0 to $1,6{ }^{\circ} \mathrm{C}$ and 0,9 to 1 , $6{ }^{\circ} \mathrm{C}$ ) of the country (Badameli and Dubreuil, 2010). The highest temperatures are registered almost each year and can reach $40{ }^{\circ} \mathrm{C}$, more often in Maritime and Savannahs regions
(Badameli and Dubreuil, 2010). Average rainfall between 1986 and 2005 has decreased from $89 \pm 22 \mathrm{~mm}$ in the whole country (DNM, 2007). From 1950 to 2000, about 27 days separate the early dates from the late dates of the start of the short rainy season in Guinean region (Adewi et al., 2010); this suggests that the potentially useful seasons has been almost inexistent in this part of the country from 1965 . Thus, agricultural schedules are disturbed by an increasingly unpredictable climate, causing soil erosion and sometimes destroying plantations, with a negative impact on crop yields (Lemou, 2008; 
Adewi et al., 2010). In some areas, crops such as maize dry before they even mature. In such a deadlock, the worst is predicted with an increasing risk of drought accompanied by a significant increase in the occurrence of extreme temperatures (IPCC, 2007).

In Togo, corn remains the first cultivated cereal crop, far in front of the sorghum, with 696 thousand hectares cultivated in 2014, for a production of about 833044 tons (FAO, 2017). However, the effectiveness of its photosynthesis, its water efficiency and its drawing root system make corn a plant very subject to water deficiency, especially since it usually ends its cycle in a period which is critical in water (Barrière, 2001).

In water deficit situation, plants develop mechanisms of tolerance (osmoregulation, activity of the antioxidant system). The accumulation of proline is one of the most remarkable osmoregulation manifestations of water and osmotic stress (Demiral and Turkan., 2004). Moreover, in view of the accumulation of reactive oxygen species (ROS), which is the cause of an oxidative stress induced by a water stress, the capacity of the antioxidant system is crucial for maintaining the integrity of the photosynthetic system. One of the mechanisms of the antioxidant system is detoxification, which consists in preventing the accumulation of hydroxides by intervening at different stages of their formation. It is found in many enzymes such as superoxide dismutases (SOD), ascorbate peroxidases (APX), catalases (CAT), glutathione-S transferases (GST) and glutathione peroxidases (GPX) (Loka et al., 2011).

The purpose of this study was to assess the contribution of an organic amendment, a compost produced from a mixture of household waste, biomass of Cassia occidentallis L., cow manure, natural phosphate and ashes of cotton seeds, as an external factor in improving corn resistance to water deficit. More specifically, the effect of this compost on the accumulation of proline and the activity of CAT and that of APX is evaluated in corn in a situation of water stress at the stages of flowering male and milky grain of its development.
MATERIALS AND METHODS

Substrates analysis and composting
materials

The sandy soil used for the purpose of the study was collected from the soil layer (0$25 \mathrm{~cm}$ depth) at the agronomic station of experiment of the Université de Lomé $\left(6^{\circ} 22^{\prime} \mathrm{N}, 1^{\circ} 13^{\prime} \mathrm{E}\right.$; altitude $\left.=50 \mathrm{~m}\right)$. It is an irontype poor which pH was 5.6., EC (dS.m-1) was 1.87 , total organic matter (TOM, \%) was 1 , total $\mathrm{C}, \mathrm{N}, \mathrm{P}, \mathrm{K}$ in $\%$ are $0.8,0.1,0.11$ and 0.026 , respectively. The collected soil was airdried, homogenized and sieved at $2 \mathrm{~mm}$. The used compost was produced from a mixture of household waste, biomass of Cassia occidentallis L., cow manure, natural phosphate and ashes of cotton seeds at ratio of 5:7:1:2:5 (m/m) (Bokobana et al., 2017). The initial material of compost was mixed and was allowed to decompose in a tank. Moisture content was measured twice a week using a thermohygrometer and was maintained at 50$60 \%$ throughout the active composting period. The mixture was turned at 2, 4, 8, 16, 30, 60 and $90^{\text {th }}$ day, to maintain porosity. The thermophilic stage $\left(>55^{\circ} \mathrm{C}\right)$ lasted for about 50 days. After 120 days of composting processes, the temperatures reached the ambient level. The compost was then left for curing about 4 weeks to be suitable as a culture medium. The compost $\mathrm{pH}$ and EC (dSm) were 6.25 and 4.44 , respectively. TOM (\%) was 47.64; total C, N, P and K (\%) dried samples were $33.98,1.73,3.13$ and 3.28 , respectively. Humic and fulvic acids contents (\%) were respectively 12.2 and 4.3 . (Bokobana et al., 2017).

\section{Plant growth and treatments}

The test was undertaken in plastic pots of $20 \mathrm{~L}(31 \mathrm{~cm}$ deep; $31 \mathrm{~cm}$ in greater diameter; $21 \mathrm{~cm}$ in lower diameter) in which holes were made at the bottom (to let drain water after watering). $500 \mathrm{~g}$ of gravel were put down at the base to allow a good drainage of water. Every pot was filled with $18 \mathrm{~kg}$ of substratum. A pre-planting irrigation was applied every 2 days at the capacity on the fields, until the sowing on the $15^{\text {th }}$ day. Maize (Zea mays L.) seeds, after kepting wet in the darkness for 72 hours, were planted, May 27, 2017 in pots (04 seeds/pot) containing sandy 
soil amended with the compost $(100 \mathrm{~g} / \mathrm{Kg}$ soil) or with chemical fertilizer (1.5 $\mathrm{g}$ of NPK 15-15-15 and $0.75 \mathrm{~g}$ of urea), and grown along with control that received no fertilizer, under natural conditions. The separation which was achieved on the $14^{\text {th }}$ day after sowing allowed to maintain one plant by pot. The environmental conditions were as follows: $12 \mathrm{~h}$ photoperiod, temperature of 26 ${ }^{\circ} \mathrm{C} / 29{ }^{\circ} \mathrm{C} / 27{ }^{\circ} \mathrm{C} 8 \mathrm{~h} / 14 \mathrm{~h} / 17 \mathrm{~h}$ and a relative humidity of $84 \%$ / 69\% / 77\%. During the growing period, the water content of the soil in all pots was maintained at $80 \%$ of the field capacity. The applied water deficit was about a lowering of the irrigation from $70 \%$ of the UWR (witness plant) to $30 \%$ of the UWR (stressed plant) at male bloom stage (right at the appearance of the panicle) and the milky grain stage (beginning of grains' filling). The UWR (in $\mathrm{mm}$ ) is given by the following formula:

U.W. R $=\sum_{h=1}^{n}[\theta f c 2,7-\theta w p 4,2) \times$ Tfine $\left.\times \mathrm{E} \times \mathrm{Da}\right] / \boldsymbol{h}$

h: Number of horizons, $\Theta_{\mathrm{fc}}$ 2,7: Moisture at field capacity in $\%, \Theta_{\mathrm{wp}} 4,2$ : Moisture at the wilting point in \%, \% Tfine: \% fine soil, E: Soil depth in dm, Da: Soil apparent density.

The irrigation of plants has been made at a periodicity of 3 days, by a weighing of pots to maintain the desired soil water levels by adding appropriate volumes of water. The experimental treatments consisted of: controls [sandy soil without fertilizer] and five treatments [sandy soil amended with compost; sandy soil added with chemical fertilizer; sandy soil under drought stress; sandy soil amended with compost under drought stress; sandy soil added with chemical fertilizer under drought stress], arranged in a split-plot design with four replicates. The experimental unit consisted of 3 pots, giving a total of 108 pots (Figure 1). After 10 days of treatment, the youngest fully developed leaves were taken for biochemical assays.

\section{Assays of antioxidant enzyme activities}

Leaf tissues $(0.5 \mathrm{~g})$ were homogenized in $4 \mathrm{ml}$ of $50 \mathrm{mM}$ sodium phosphate buffer ( $\mathrm{pH}$ 7.0) containing $1 \mathrm{mM}$ ethylenediamine tetraacetic acid (EDTA), $1 \mathrm{mM}$ ascorbic acid and $1 \%$ $(\mathrm{w} / \mathrm{v})$ polyvinylpyrrolidone (PVP) in an ice bath. The homogenate was centrifuged at 4
${ }^{\circ} \mathrm{C} / 14000 \mathrm{rpm}$ for 10 minutes. The resulting supernatant was used for assays of the activities of CAT (EC 1.11.1.6) and APX (EC 1.11.1.11) according to the method described by Parida et al. (2004). The determination of protein content in the enzyme extract by the method of Bradford (1976) has permitted to calculate CAT and APX activities by the following formulas:

$\operatorname{Act} . \mathrm{CAT}=(\Delta \mathrm{Abs} \times \mathrm{v}) /(\varepsilon 240 \times \mathrm{L} \times \Delta \mathrm{t} \times \mathrm{T} \times \mathrm{m})$

Act. CAT: Catalase activity $\left(\mu \mathrm{mol} \mathrm{H}_{2} \mathrm{O}_{2} \cdot \mathrm{mg}\right.$ ${ }^{1}$ protein. $\left.\min ^{-1}\right) ; \Delta$ Abs: Average Difference in absorbance; $\varepsilon$ 240: Molar linear extinction coefficient $\left(39,4 \mathrm{mM}^{-1} \cdot \mathrm{cm}^{-1}\right)$; L: Diameter of the tank $(\mathrm{cm})$; v: Volume of the reaction mixture $(\mathrm{mL})$; m: Sample mass used for the enzymatic extract $(\mathrm{g}) ; \mathrm{T}$ : Protein content $\left(\mathrm{mg} . \mathrm{g}^{-1}\right) ; \Delta \mathrm{t}:$ Culture time (min).

Act.APX $=(\Delta$ Abs x v) $/(\varepsilon 290 \times$ L x $\Delta$ t $\times$ T x m $)$

Act: Ascorbate peroxidase activity ( $\mu \mathrm{mol}$ ascorbate. $\mathrm{mg}^{-1}$ protein. $\left.\mathrm{min}^{-1}\right) ; \Delta$ Abs: Average Difference in absorbance; $\varepsilon$ 290: Molar linear extinction coefficient $\left(34 \mathrm{mM}^{-1} \cdot \mathrm{cm}^{-1}\right)$; L: Diameter of the tank $(\mathrm{cm})$; v: Volume of the reaction mixture $(\mathrm{mL}) ; \mathrm{m}$ : Sample mass used for the enzymatic extract $(\mathrm{g})$; $\mathrm{T}$ : Protein content $\left(\mathrm{mg} \cdot \mathrm{g}^{-1}\right) ; \Delta \mathrm{t}$ : Culture time (min).

\section{Measure of leaf proline content}

The proline assay adapted to the leaf was performed according to Bogdanov method (1999). At $510 \mathrm{~nm}$ the absorbance of the leaf extract $\left(25 \mathrm{mg} \cdot \mathrm{mL}^{-1}\right.$ of water) and the absorbance of standard proline solutions (32 $\mu \mathrm{g} . \mathrm{ml}^{-1}$ ) were taken to deduce the proline content (expressed in $\mu \mathrm{g}$ proline. $\mathrm{mg}^{-1}$ protein) in the extract. A $5 \mathrm{~mL}$ test tube contained 0.5 $\mathrm{mL}$ of standard proline or ground the leaf or water for the blank received $1 \mathrm{~mL}$ of formic acid $100 \%$ and $1 \mathrm{~mL}$ ethylene glycol $3 \%$. After a vigorous mixing during 15 minutes at room temperature each tube was placed 15 minutes in a boiling bath. $2.5 \mathrm{~mL}$ of 2 propanol $50 \%$ were added in each tube then placed for 10 minutes in a water bath of 70 ${ }^{\circ} \mathrm{C}$. When the tube took the room temperature 45 minutes later $1 \mathrm{~mL}$ was taken of its content of the absorbance reading at $510 \mathrm{~nm}$ with a 
spectrophotometer. The proline content of the leaves, estimated in $\mu \mathrm{g} \cdot \mathrm{mg}^{-1}$ of proteins, was determined by the following formula:

$\mathrm{P}=(\mathrm{Ae} / \mathrm{As} \times \mathrm{Ms} / \mathrm{Mf}) / \mathrm{Qp}$

P: Proline content (mg. $\left.\mathrm{g}^{-1} \mathrm{mf}\right)$; Ae: Absorbance of the leaf extract; As: Absorbance of standard proline solution; Ms: Proline mass of the standard solution $(\mu \mathrm{g})$; Mf: Leaf fresh mass (g); Proteins content (mg.g. ${ }^{-1}$ fresh matter).

\section{Dry aerial biomass measurement}

Plants were harvested on the 10 day of exposure to the drought when they were 90 days old. The dry aerial biomass (DAB) was measured after drying samples in an oven at $70{ }^{\circ} \mathrm{C}$ for 2 days.

\section{Statistical analysis}

The data were subjected to statistical analysis using STATISTICA software (version 6.0). Student Newman-Keuls test was applied to compare the treatment means. Any variable with a $\mathrm{P}$ value less than or equal to 0.05 is considered as significant. Two classification factors were used, the standard factor of fertilization and the stage of application of the water deficit. A calculation of the rate of change (S) of the measured parameter was performed.

$$
\mathrm{S}=[(\mathrm{Vs}-\mathrm{Vt}) / \mathrm{Vt}] \times 100
$$

S: Incidence of the water deficit; Vs: Value of stressed; Vt: Value of the witness.

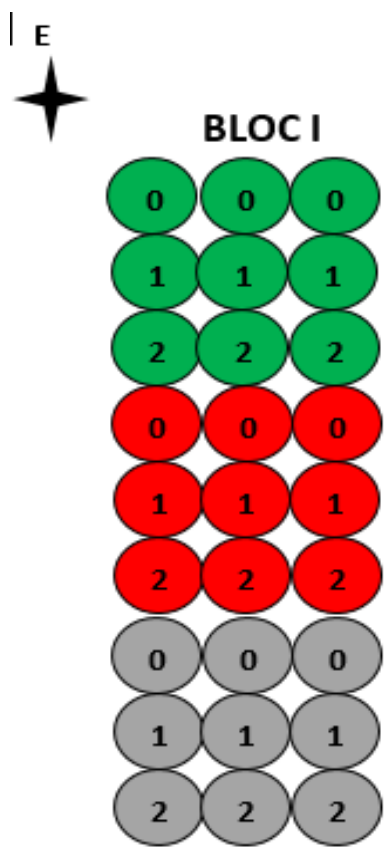

Without fertilization

Compost

Synthetic fertilizer
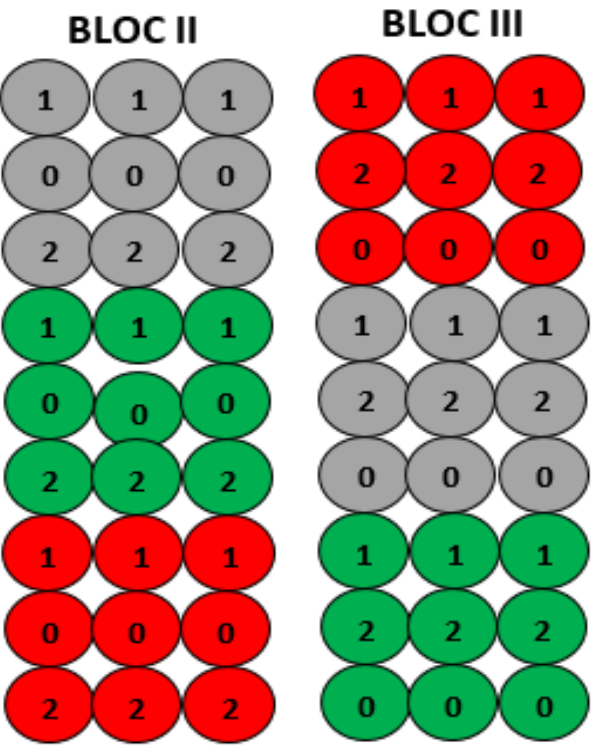

BLOC IV

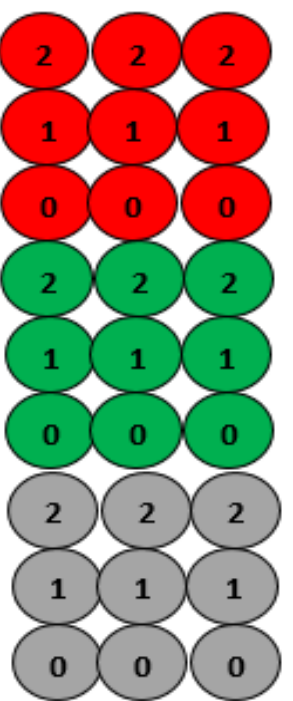

\section{0 : Normal irrigation (70\% of the RNW)}

1: Water deficit at male bloom stage ( $30 \%$ of the RNW)

2 : Water deficit at milky grain stage ( $30 \%$ of the RNW)

Figure 1: Experimental device (Split Plot 3 x 4). 


\section{RESULTS}

The analysis of the variance (Tables 1 and 2) shows that the water regime, fertilization and interaction of both factors had a highly significant effect ( $p=0.00000$ to $p$ $<0.05)$ on the proline content and on the activity of CAT and APX at the leaf level. However, specificities in the variations of the variables measured are to be observed from one type of fertilization to another and following the phenological stage of the plant where the water deficit was applied.

\section{Proline content of leaves}

The proline content of leaves has significantly increased with the application of water deficit whatever the treatment (Table 3). Soil fertilization has significantly influenced the accumulation of proline at the foliar level. Indeed, this accumulation is higher in plants that are cultivated on compost (80.58 to $160.45 \%$ ) than in those that are grown on chemical fertilizer (48.25 to $106.98 \%$ ) (Figure $2 \mathrm{~A})$. Depending on the date of application of the water deficit, the accumulation rate of proline is significantly higher at the male flowering stage (106.98 to $160.45 \%)$ than at the milky grain stage (48.25 to $80.58 \%)$ (Figure 2B).

\section{CAT and APX activities in the leaves}

The water deficit led to an increase in catalase activity (Table 4) and ascorbate peroxidase activity (Table 5) in the leaves whatever the treatment. Depending on the type of fertilization, the rates of increase in catalase and ascorbate peroxidase activities remain significantly higher in plants grown on compost (22.71 to $75.34 \%$ for CAT activity; 57.35 to $63.08 \%$ for APX activity) than in plants grown on synthetic fertilizer (15.10 to $40.45 \%$ for CAT activity; 35.29 to $45.66 \%$ for APX activity) (Figures 3A and 4A). Depending on the date of application of water deficiency, only CAT activity remains significantly higher in the milky grain stage than in the male bloom stage (40.45 to $75.34 \%$ for milky grain stage; 15.10 to $22.71 \%$ for male bloom stage) (Figure 3B), when the differences in the APX activity remain non-significant (Figures $4 \mathrm{~A}$ and $4 \mathrm{~B}$ ).

\section{Analysis of the correlation}

Under normal irrigation, the analysis of the correlation matrix (Table 6) show positive significant correlation between CAT and APX activities $(r=1.000 ; p=0.014)$ at male bloom stage. In water deficit condition, and at male bloom stage, the analysis of the correlation matrix (Table 7) show positively significant correlation between CAT and APX activities $(\mathrm{r}=0.997 ; \mathrm{p}=0.048)$ and on the other hand between proline content and CAT activity $(\mathrm{r}=$ 1.000; $\mathrm{p}=0.012)$ and APX activity $(\mathrm{r}=0.998$; $\mathrm{p}=0.036$ ). At milky grain stage, positive significant correlation was observed between CAT an APX activities ( $r=0.998 ; p=0.036)$, and on the other hand between CAT activities and proline content $(r=0.998 ; p=0.042)$.

\section{Dry aerial biomass}

The analysis of the variances (Tables 8) shows that the water regime, fertilization and interaction of the both factors had a significant effect on dry aerial biomass. Water deficit significantly reduced dry aerial biomass (DAB) (Table 9). Compost crops were less affected by this decline, at only $2.63 \%$ and $2.25 \%$, respectively, at the male bloom stage and the milky-grained stage (Figure 5A). On the other hand, the decrease in DAB is significantly greater for the water deficit applied to the male bloom stage, with decline rates respectively of $13.27 \%, 5.15 \%$ and $2.63 \%$, compared with $8.22 \%, 2.31 \%$ and $2.25 \%$ for the water deficit applied to the milky-grained stage (Figure 5B). 
Table 1: Analysis of the variance of proline content (Prol), catalase activity (Act. CAT) and ascorbate peroxidase activity (Act. APX) at the male bloom stage.

\begin{tabular}{|c|c|c|c|c|c|c|c|}
\hline \multirow[t]{3}{*}{ Source } & \multirow{3}{*}{ dl } & \multicolumn{2}{|c|}{ Prol. } & \multicolumn{2}{|c|}{ Act. CAT } & \multicolumn{2}{|c|}{ Act. APX } \\
\hline & & MS & $\mathbf{P}$ & MS & $\mathbf{P}$ & MS & $\mathbf{P}$ \\
\hline & & \multicolumn{2}{|c|}{$\mathbf{F}$} & \multicolumn{2}{|c|}{$\mathbf{F}$} & \multicolumn{2}{|c|}{$\mathbf{F}$} \\
\hline \multirow[t]{2}{*}{ WR } & 1 & 0.48 & $* * *$ & 150.95 & $\mathrm{~ns}$ & 0.13 & * \\
\hline & & 39.6231 & & 1.37568 & & 12.1 & \\
\hline \multirow[t]{2}{*}{ Fertilization } & 2 & 0.11 & $*$ & 1989.60 & $* *$ & 0.59 & $* * *$ \\
\hline & & 5.108608 & & 13.2652 & & 35.5 & \\
\hline \multirow[t]{2}{*}{ WR*Fertilization } & 5 & 9.95 & $* * *$ & 5370.24 & $* * *$ & 2.04 & *** \\
\hline & & 379.9663 & & 37.8312 & & 136.8 & \\
\hline
\end{tabular}

MS = mean square; $\mathrm{dl}$ : free level; $\mathrm{WR}=$ water regime; $\mathrm{F}=$ Fisher factor; $\mathrm{P}=$ significance; * = Significant at the $5 \%$ threshold; $* *=$ significant at $1 \%$ threshold; $* * *=$ significant at the $0.1 \%$ threshold; $\mathrm{ns}=$ not significant.

Prol: proline content; Act. CAT: catalase activity; Act. APX: ascorbate peroxidase activity.

Table 2: Analysis of the variance of proline content (Prol), catalase activity (Act. CAT) and ascorbate peroxidase activity (Act. APX) at the milky grain stage.

\begin{tabular}{|c|c|c|c|c|c|c|c|}
\hline \multirow[t]{3}{*}{ Source } & \multirow{3}{*}{ dl } & \multicolumn{2}{|c|}{ Prol. } & \multicolumn{2}{|c|}{ Act. CAT } & \multicolumn{2}{|c|}{ Act. APX } \\
\hline & & MS & $\mathbf{P}$ & MS & $\mathbf{P}$ & MS & $\mathbf{P}$ \\
\hline & & \multicolumn{2}{|c|}{$\mathbf{F}$} & \multicolumn{2}{|c|}{$\mathbf{F}$} & \multicolumn{2}{|c|}{$\mathbf{F}$} \\
\hline \multirow{2}{*}{ WR } & 1 & 0.14 & * & 276.95 & * & 0.36 & ** \\
\hline & & \multicolumn{2}{|c|}{13.13461} & 7.6647 & & \multicolumn{2}{|c|}{29.17227} \\
\hline \multirow[t]{2}{*}{ Fertilization } & 2 & 0.10 & As & 1850.31 & $* *$ & 1.20 & $* * *$ \\
\hline & & \multicolumn{2}{|c|}{2.705949} & 16.253 & & \multicolumn{2}{|c|}{218.7752} \\
\hline \multirow[t]{2}{*}{ WR* fertilization } & 2 & 3.42 & $* * *$ & 31755.77 & $* * *$ & 3.91 & $k * *$ \\
\hline & & \multicolumn{2}{|c|}{68.35817} & 245.74 & & \multicolumn{2}{|c|}{315.1543} \\
\hline
\end{tabular}

$\mathrm{MS}=$ mean square; $\mathrm{ddl}$ : free level; $\mathrm{WR}=$ water regime; $\mathrm{F}=$ Fisher factor; $\mathrm{P}=$ significance; $*$ Significant at the $5 \%$ threshold; $* *=$ significant at $1 \%$ threshold; $* * *=$ significant at the $0.1 \%$ threshold; $\mathrm{ns}=$ not significant.

Prol: proline content; Act. CAT: catalase activity; Act. APX: ascorbate peroxidase activity.

Table 3: Variation in proline content (mg.g $\left.{ }^{-1} \mathrm{mf}\right)$.

\begin{tabular}{clcc}
\hline Water regime & Fertilization & Male bloom stage & Milky grain stage \\
\hline \multirow{2}{*}{ Normal } & Without fertilization & $1.91 \pm 0.11^{\mathbf{d}}$ & $2.27 \pm 0.09^{\mathbf{d}}$ \\
& Synthetic fertilizer & $2.18 \pm 0.15^{\mathbf{c d}}$ & $2.54 \pm 0.24^{\mathbf{c}}$ \\
& Compost & $2,21 \pm 0.18^{\mathbf{c d}}$ & $2.55 \pm 0.21^{\mathbf{c}}$ \\
& & & \\
\multirow{2}{*}{ Deficit } & Without fertilization & $2.39 \pm 0.11^{\mathbf{c}}$ & $2.54 \pm 0.12^{\mathbf{c}}$ \\
& Synthetic fertilizer & $4.51 \pm 0.26^{\mathbf{b}}$ & $3.75 \pm 0.23^{\mathbf{b}}$ \\
& Compost & $5.73 \pm 0.11^{\mathbf{a}}$ & $4.60 \pm 0.35^{\mathbf{a}}$ \\
\hline
\end{tabular}

Values with the same letter (s) in the same column are not significantly different from the probability threshold of 0.05 (Newman-Keuls). 

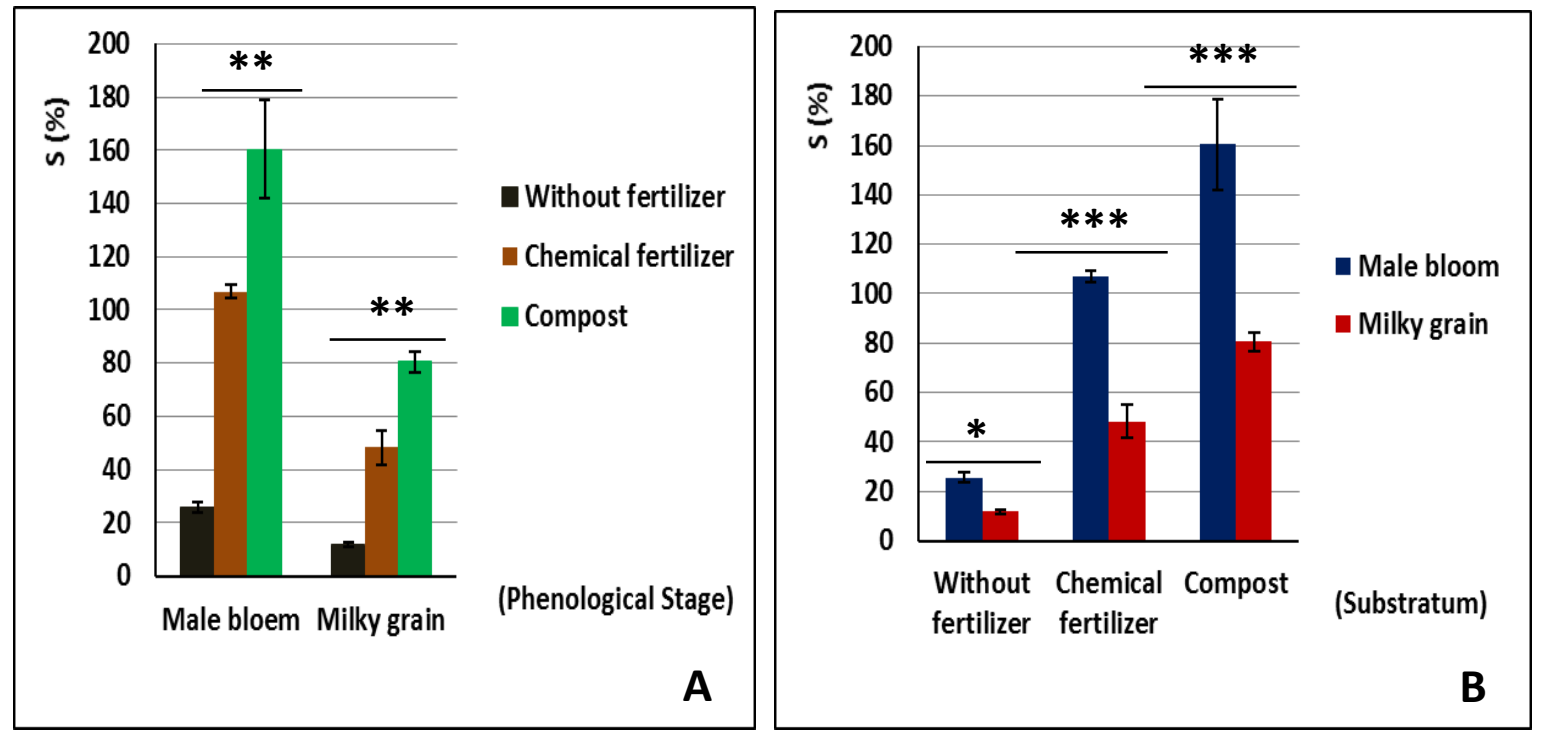

Figure 2: Leaves proline accumulation rate under water deficit, (A) According to the type of fertilizer, (B) According to the date of application of the water deficit. S: rate of change; * $\mathrm{P} \leq 0.05$ $* * \mathrm{p} \leq 0.01 ; * * * \mathrm{p} \leq 0.001 ;$ ns: not significant.

Table 4: Variation in CAT activity $\left(\mu \mathrm{mol} \mathrm{H}_{2} \mathrm{O}_{2} \cdot \mathrm{mg}^{-1}\right.$.prot.min $\left.{ }^{-1}\right)$.

\begin{tabular}{|c|c|c|c|}
\hline Water regime & Fertilization & Male bloom stage & Milky grain stage \\
\hline Normal & $\begin{array}{l}\text { Without fertilization } \\
\text { Synthetic fertilizer } \\
\text { Compost }\end{array}$ & $\begin{array}{l}1.41 \pm 0.12^{\mathrm{e}} \\
1.97 \pm 0.18^{\mathrm{c}} \\
2.14 \pm 0.05^{\mathrm{c}}\end{array}$ & $\begin{array}{l}1.55 \pm 0.06^{\mathrm{e}} \\
2.12 \pm 0.09^{\mathrm{d}} \\
2.64 \pm 0.06^{\mathrm{c}}\end{array}$ \\
\hline Deficit & $\begin{array}{l}\text { Without fertilization } \\
\text { Synthetic fertilizer } \\
\text { Compost }\end{array}$ & $\begin{array}{l}1.66 \pm 0.08^{d} \\
2.66 \pm 0.16^{b} \\
3.37 \pm 0.10^{a}\end{array}$ & $\begin{array}{l}1.97 \pm 0.14^{d} \\
3.09 \pm 0.16^{b} \\
4.31 \pm 0.11^{\mathrm{a}}\end{array}$ \\
\hline
\end{tabular}

$\overline{\text { Values with the same letter (s) in the same column are not significantly different from the probability threshold of } 0.05}$ (Newman-Keuls).

Table 5: Variation in APX activity ( $\mu \mathrm{mol}$ ascorbate. $\mathrm{mg}^{-1} \cdot$ prot. $\left.\mathrm{min}^{-1}\right)$.

\begin{tabular}{|c|c|c|c|}
\hline Water regime & Fertilization & Male bloom stage & Milky grain stage \\
\hline Normal & $\begin{array}{l}\text { Without fertilization } \\
\text { Synthetic fertilizer } \\
\text { Compost }\end{array}$ & $\begin{array}{l}20.09 \pm 1.24^{d} \\
23.31 \pm 1.38^{c} \\
24.38 \pm 1.03^{c}\end{array}$ & $\begin{array}{l}21.05 \pm 0.81^{d} \\
24.17 \pm 1.28^{c} \\
25.18 \pm 1.06^{c}\end{array}$ \\
\hline Deficit & $\begin{array}{l}\text { Without fertilization } \\
\text { Synthetic fertilizer } \\
\text { Compost }\end{array}$ & $\begin{array}{l}20.96 \pm 0.81^{\mathbf{d}} \\
26.79 \pm 0.89^{\mathbf{b}} \\
29.88 \pm 1.60^{\mathbf{a}}\end{array}$ & $\begin{array}{l}22.23 \pm 0.26^{\mathrm{cd}} \\
33.83 \pm 1.60^{\mathbf{b}} \\
44.12 \pm 1.30^{\mathbf{a}}\end{array}$ \\
\hline
\end{tabular}

Values with the same letter (s) in the same column are not significantly different from the probability threshold of 0.05 (Newman-Keuls). 
Table 6: Correlation matrix (Pearson) between biochemical variables under normal irrigation.

\begin{tabular}{lcccccc}
\hline & \multicolumn{3}{c}{ Male bloom stage } & \multicolumn{3}{c}{ Milky grain stage } \\
\hline \multicolumn{1}{c}{ Variables } & Prol. & Act.CAT & Act.APX & Prol. & Act.CAT & Act.APX \\
\hline Prol. & $\mathbf{1}$ & & & $\mathbf{1}$ & & \\
Act.CAT & 0.986 & $\mathbf{1}$ & & 0.981 & $\mathbf{1}$ & \\
Act.APX & 0.990 & $\mathbf{1 . 0 0 0}$ & $\mathbf{1}$ & 0.898 & 0.967 & $\mathbf{1}$ \\
\hline
\end{tabular}

Numbers in bold = significant Pearson correlation coefficient at $5 \%$

Prol.: proline content; Act. CAT: catalase activity; Act. APX: ascorbate peroxidase activity.

Table 7: Correlation matrix (Pearson) between biochemical variables under water deficit.

\begin{tabular}{lcccccc} 
& \multicolumn{3}{c}{ Male bloom stage } & \multicolumn{3}{c}{ Milky grain stage } \\
\hline \multicolumn{1}{c}{ Variables } & Prol. & Act.CAT & Act.APX & Prol. & Act.CAT & Act.APX \\
\hline Prol. & $\mathbf{1}$ & & & $\mathbf{1}$ & & \\
Act.CAT & $\mathbf{1 . 0 0 0}$ & $\mathbf{1}$ & & $\mathbf{0 . 9 9 8}$ & $\mathbf{1}$ & \\
Act.APX & $\mathbf{0 . 9 9 8}$ & $\mathbf{0 . 9 9 7}$ & $\mathbf{1}$ & 0.993 & $\mathbf{0 . 9 9 8}$ & $\mathbf{1}$ \\
\hline
\end{tabular}

Numbers in bold = significant Pearson correlation coefficient at 5\%

Prol.: proline content; Act. CAT: catalase activity; Act. APX: ascorbate peroxidase activity.

Table 8: Analysis of the variance of dry aerial biomass (DAB) at the different stages.

\begin{tabular}{|c|c|c|c|c|c|}
\hline \multirow[b]{2}{*}{ Source } & \multicolumn{3}{|c|}{ Male bloom stage } & \multicolumn{2}{|c|}{ Milky-grained stage } \\
\hline & dl & MS & $\mathbf{P}$ & MS & $\mathbf{P}$ \\
\hline WR & 1 & 380.81 & $* *$ & 146.42 & $* * *$ \\
\hline Fertilization & 2 & 9974.70 & $* * *$ & 9974.70 & $* * *$ \\
\hline WR*Fertilization & 5 & 7465.32 & $* * *$ & 7807.57 & \\
\hline
\end{tabular}

MS = mean square; dl: free level; WR = water regime; $\mathrm{F}=$ Fisher factor; $\mathrm{P}=$ significance; * = significant at the 5\% threshold; $* *=$ significant at $1 \%$ threshold $; * *=$ significant at the $0.1 \%$ threshold; $\mathrm{ns}=$ not significant.

Table 9: Variation in dry aerial biomass (g).

\begin{tabular}{cll}
\hline Water regime & Fertilization & DAB $(\mathbf{g})$ \\
\hline \multirow{2}{*}{ Normal } & Without fertilization & $135.95 \pm 3.48^{\mathbf{d}}$ \\
& Synthetic fertilizer & $220.12 \pm 3.74^{\mathbf{b}}$ \\
& Compost & $233.79 \pm 1.42^{\mathbf{a}}$ \\
Deficit at Male bloom stage & Without fertilization & $120.02 \pm 1.47^{\mathbf{f}}$ \\
& Synthetic fertilizer & $209.4 \pm 6.19^{\mathbf{c}}$ \\
Deficit at Milky-grained stage & Compost & $227.82 \pm 2.97^{\mathbf{a}}$ \\
& Without fertilization & $129.90 \pm 3.14^{\mathbf{d}}$ \\
& Synthetic fertilizer & $219.18 \pm 1.42^{\mathbf{b}}$ \\
& Compost & $232.95 \pm 3.65^{\mathbf{a}}$ \\
\hline
\end{tabular}

Values with the same letter (s) in the same column are not significantly different from the probability threshold of 0.05 (Newman-Keuls). DAB= dry aerial biomass. 

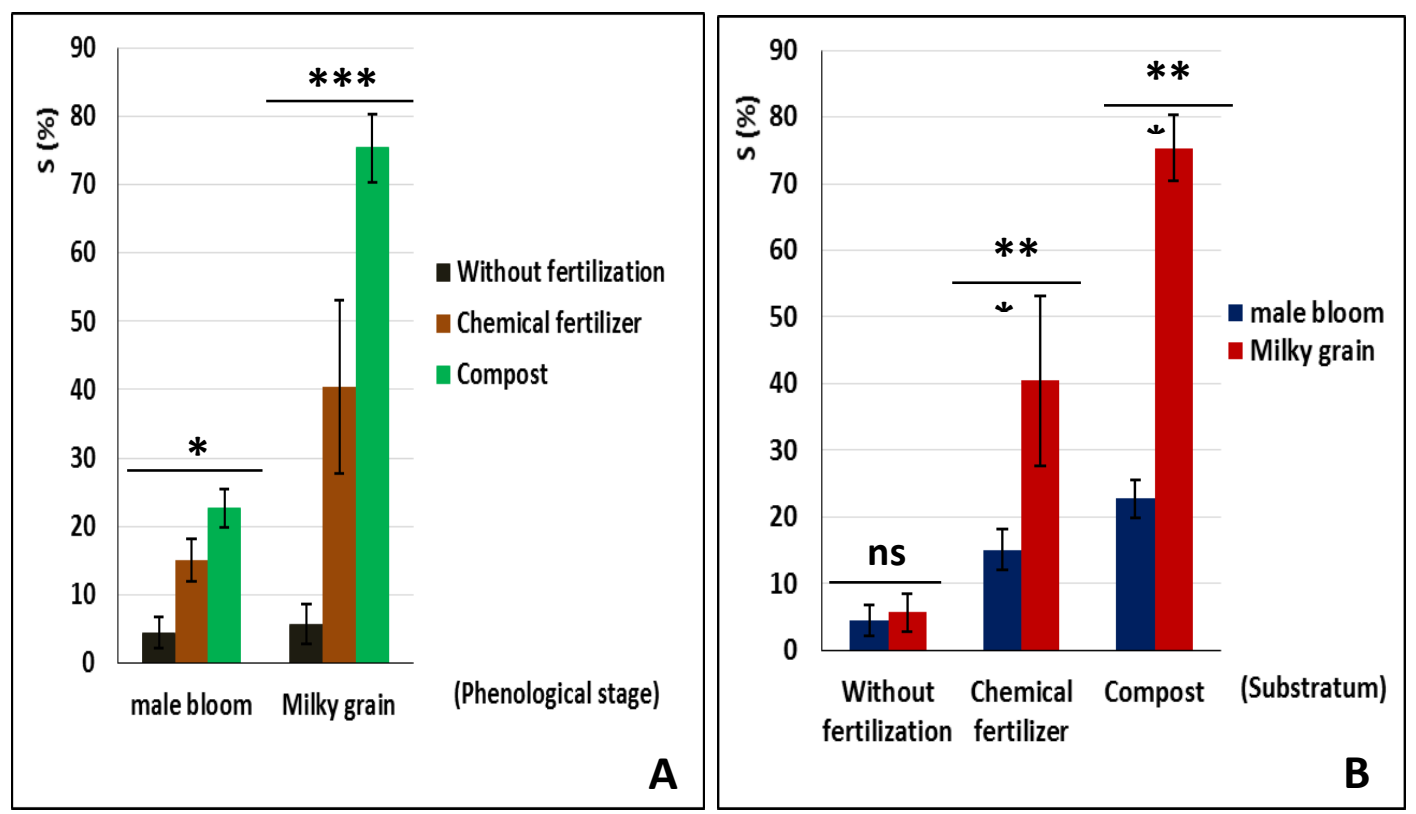

Figure 3: Catalase activity increase rate under water deficit, (A) according to the type of fertilizer, (B) according to the date of application of the water deficit. S: rate of change; * $\mathrm{P} \leq 0.05 ;{ }^{* *} \mathrm{p} \leq 0.01$; *** $\mathrm{p} \leq 0.001$; ns: not significant.
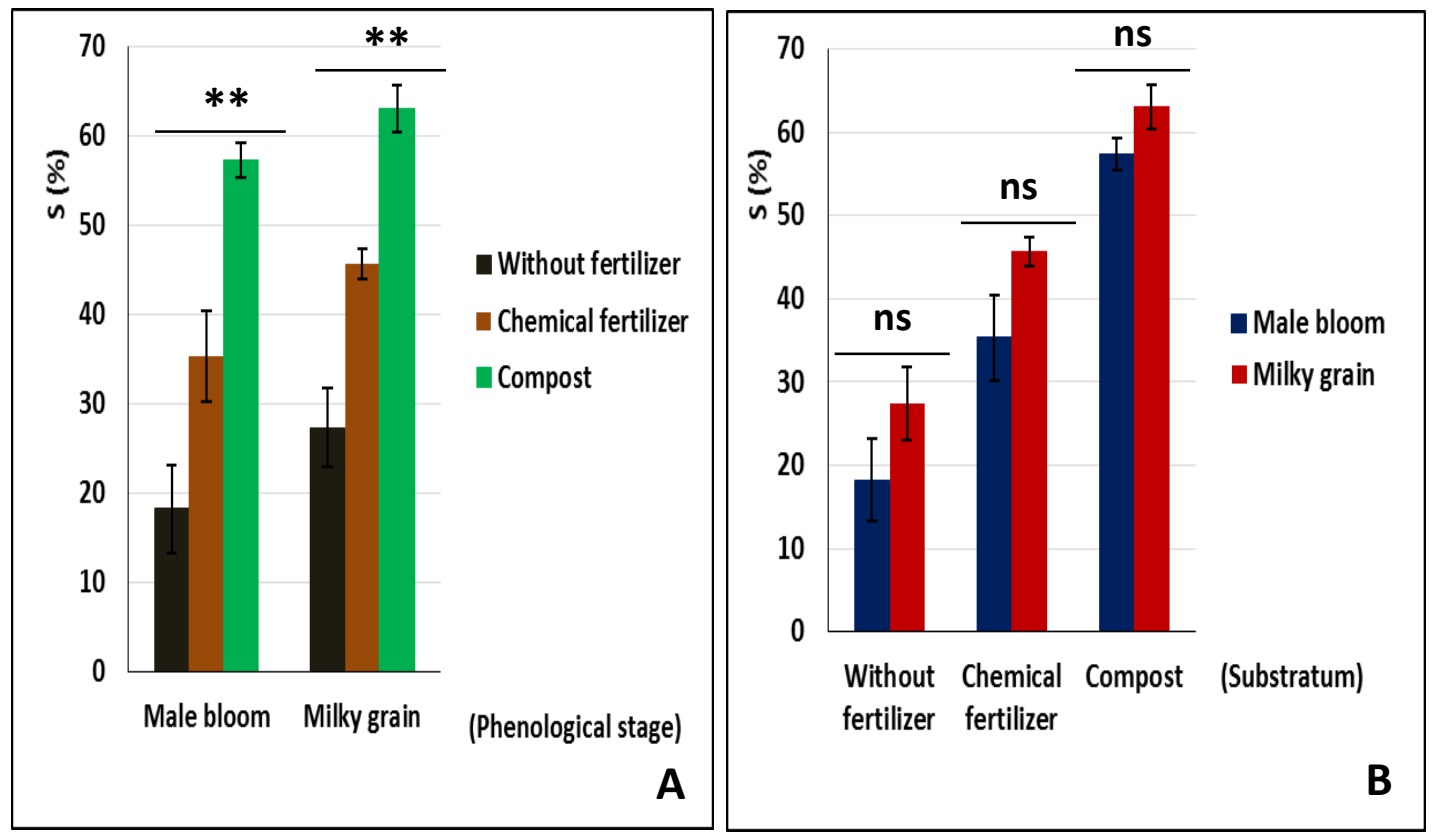

Figure 4: Ascorbate peroxidase activity increase rate under water deficit, (A) according to the type of fertilizer, (B) according to the date of application of the water deficit. S: rate of change; * $\mathrm{P} \leq 0.05$; ** $\mathrm{p} \leq 0.01 ; * * * \mathrm{p} \leq 0.001 ;$ ns: not significant. 

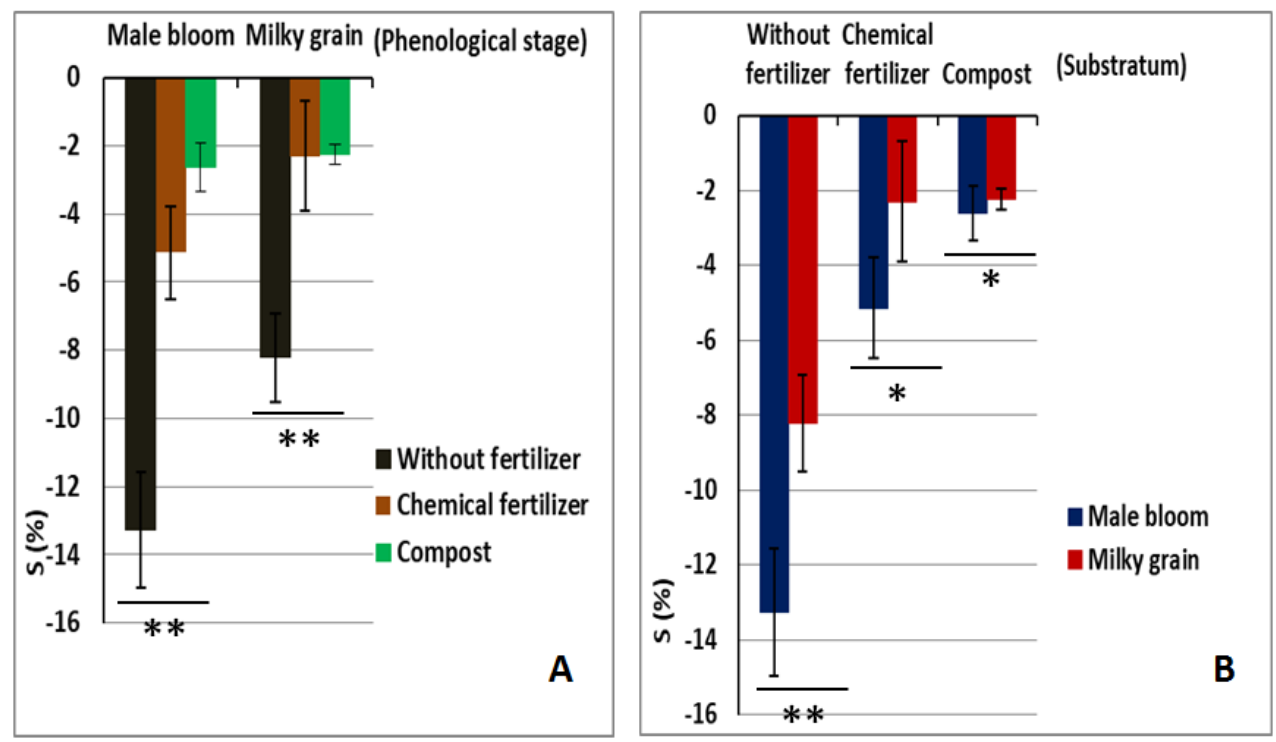

Figure 5: Dry aerial biomass decrease rate under water deficit, (A) according to the type of fertilizer, (B) according to the date of application of the water deficit. S: rate of change; ${ }^{*} \mathrm{P} \leq 0.05$; ** $\mathrm{p} \leq 0.01 ; * * * \mathrm{p} \leq 0.001 ;$ ns: not significant.

\section{DISCUSSION}

Proline accumulation under drought conditions may be the result of three complementary processes: stimulation of its synthesis, inhibition of its oxidation and / or alteration of protein biosynthesis (Sandhya et al., 2010). The accumulated proline could play a role of osmoticum (Demiral and Turkan, 2004), and would intervene in the strengthening of the antioxidant system and the fight against stress damage (Molinari et al., 2007). This indicates the high positive correlations between the proline content and the activity of catalase and ascorbate peroxidase. Proline could also be incorporated into parietal proteins, allowing remodeling of the wall for strengthening (Ben $\mathrm{Nja}$, 2014). It could also play a role in the regulation of cytoplasmic $\mathrm{pH}$ or constitute a nitrogen reserve used by the plant after the period of water deficit (Kavi Kishor et al., 2005). Given this role devolved to proline, the accumulated quantities could be linked to the level of tolerance to the water deficit (Ouiza et al., 2010). Thus, the high accumulation rates in plants grown on compost are proof that organic matter would raise the tolerance level of the plant to water deficit (Tartoura, 2010; Some et al., 2010).
Water deficiency induced an increase in the activity of catalase and ascorbate peroxidase. Similar results have been reported by many researchers in other abiotic stress studies (Caverzan et al., 2012; Sofo et al., 2015). These results indicate that both enzymes are involved in the cellular $\mathrm{H}_{2} \mathrm{O}_{2}$ catabolism that is harmful to cellular integrity (Meksem, 2007). The rates of increase in catalase and ascorbate peroxidase activity remained significantly higher in plants grown on compost than in plants grown on chemical fertilizer. Shigoeka et al. (2002) demonstrate a close relationship between the increase in ascorbate peroxidase activity and the intensity of water deficiency in the cell. The increased enzyme activity of the antioxidant system was positively correlated with plant resistance to drought (Halliwell, 2006). Moreover, it's found that drought-resistant crop strains had higher levels of antioxidant enzymes than drought-sensitive strains (Laxa et al., 2019). According to Tartoura (2010) and Verma et al. (2014), waste compost improves wheat resistance to water deficiency through an accumulation of enzymes such as APX, CAT and GPX, unlike plants grown on a substrate without amendment. Thus, organic amendments, through their composition in micronutrients and organic matter, would 
strengthen the defense system developed by plants in a situation of water stress.

The effect of composts on the biochemical stress indicators found in this study would be associated to the presence in the compost of macro and micronutrients (magnesium, calcium, potassium), organic matter, phytohormone-like substances, biotic agents, carbon dioxide, nitric oxide and many others, leading to the synthesis and accumulation of several metabolites (Jia et al., 2010). In addition to nutrients and organic matter, compost contains a significant amount of humic substances (Francou, 2003). Humic substances are natural organic polyelectrolytes (Chen et al., 2004a). Among the various functional actions of humic substances, their ability to improve plant growth has been well established in various species (Chen et al., 2004b). However, the mechanism behind the action of humic substances is poorly understood. While some authors suggest that humic substances promote plant growth by improving the bioavailability of certain nutrients in soil, mainly iron and zinc (Chen et al., 2004a; Chen et al., 2004b), others suggest that humic substances can also directly affect plant metabolism (Some et al., 2010).

The variability of the biochemical parameters measured from one phenological stage to another could be associated on the one hand with the physiological age of the plant (senescence) but on the other hand with the growth conditions (Valentinuz and Tollenaar, 2004). During the filling phase of the grains, the lack of water causes an accelerated senescence of the leaves.

The study showed also that corn further reduces its aboveground biomass under dry conditions. Similar results have already been obtained by Meskelu et al. (2014). This reduction is explained by Imorou et al. (2018) by reducing the leaf area (photosynthesis site) and stem elongation, by decreasing the number of grains due to poor fertilization (at bloom stage) or by the reduced accumulation of starch in the endosperm (at the milky-grained stage). However, this decrease in aerial biomass remains low for compost crops in favor of grain production and filling (Imorou et al., 2018).

\section{Conclusion}

The analysis of biochemical indicators of water stress in maize accounts for the effect of fertilization on the metabolism linked to the plant's resistance to drought. Thus, the synthetic voices of osmolytes (proline) in the fight against the effects of water stress, as well as the activity of the enzymes of the antioxidant system (CAT and APX) would be significantly stimulated by chemical factors present in organic matter. This would considerably reduce the damage caused by water stress to the development of the plant. This study shows that, besides improving the physical and chemical properties of the soil, compost offers the plant a better metabolic predisposition to withstand the effects of drought. However, the evaluation of the performance components can validate the metabolic flexibility obtained in this chapter.

\section{COMPETING INTERESTS}

The authors declare that they have no competing interests.

\section{AUTHORS' CONTRIBUTIONS}

All authors contributed to the realization of this work. They also read and approved this manuscript.

\section{ACKNOWLEDGMENTS}

Appreciation is extended to Drs $\mathrm{K}$. Etsè and M. Mamatchi for their helpful comments on the manuscript and to Togolese Institute for Agricultural Research (ITRA) for able technical assistance.

\section{REFERENCES}

Adewi A, Badameli KMS, Dubreuil V. 2010. Evolution des saisons de pluies potentiellement utiles au Togo de 1950 à 2000. Climatologie, 7 : 89-108. DOI : halshs-00560657

Badameli A, Dubreuil V. 2010. Diagnostic du changement climatique au Togo à travers l'évolution de la température entre 1961 et 2010. XXVIIIe Colloque de l'Association Internationale de Climatologie, Jul 2015, Liège, Belgique. pp.421-426, Actes du XXVIIIe Colloque de l'Association Internationale de Climatologie. DOI: halshs-01176808

Barrière Y. 2001. Le maïs et l'eau : une situation aujourd'hui paradoxale, mais des progrès génétiques à attendre d'un idéotype redéfini. Fourrages, 168: 477 489. 
Ben Nja R. 2014. Effet d'un stress salin sur la teneur en polymères pariétaux dans les feuilles de luzerne (Medicago sativa cv Gabès) et sur la distribution dans les cellules de transfert des fines nervures. Thèse de Doctorat, Université Limoges \& Carthage, p. 179.

Bogdanov S. 1999. Harmonised methods of the international honey commission. Swiss Bee Research Center, FAM, Liebefeld, CH-3003 Bern, Switzerland, p. 62

Bokobana A, Toundou O, Kolani L, Amouzouvi KAA, Koledzi E, Tozo K, Tchangbedji G. 2017. Traitement de déchets ménagers par co-compostage avec la légumineuse Cassia occidentalis L. et quelques adjuvants de proximité pour améliorer la qualité agronomique de composts. Déchets Science Technique, 73: 118-126. DOI: https://doi.org/10.4267/dechetssciences-techniques.3551

Bradford MM. 1976. A rapid and sensitive method for the quantitation of microgram quantities of protein utilizing the principle of protein-dye binding. $J$. Biol. Chem., 72: 248-254. DOI: http://dx.doi.org/10.1016/00032697(76)90527-3

Caverzan A, Passaia G, Rosa SB, Ribeiro CW, Lazzarotto F, Margis-Pinheiro M. 2012. Plant responses to stresses: Role of ascorbate peroxidase in the antioxidant protection. Genet. Mol. Biol., 35(4): 1011-1019. DOI: http://dx.doi.org/10.1590/S141547572012000600016

Chen Y, Clapp C, Magen H. 2004a. Mechanism of plant growth stimulation by humic substances: The role of organo-iron complexes. Soil Sci. Plant Nutr., 50: $1089-1095 . \quad$ DOI: 10.1080/00380768.2004.10408579

Chen Y, De Nobili M, Aviad T. 2004b. Stimulatory effects of humic substances on plant growth. In: Soil Organic Matter in Sustainable Agriculture. CRC Press, Boca Raton, Florida; 103-129.

Demiral T, Türkan I. 2004. Comparative lipid peroxidation, antioxidant defense systems and proline content in roots of two rice cultivars differing in salt tolerance. Environ. Exp. Bot., 53: 247-
257.

DOI:

10.1016/j.envexpbot.2004.03.017

DNM (Direction Nationale de la Météorologie). 2007. Etude sectorielle, Etablissement humains et santé. Rapport d'étude, p. 10.

FAO (Food and Agriculture Organization). 2017. www.fao.org/faostat/en/\# countrt

Francou C. 2003. Stabilisation de la matière organique au cours du compostage de déchets urbains : Influence de la nature des déchets et du procédé de compostage - Recherche d'indicateurs pertinents. Thèse de Doctorat, Institut national agronomique Paris- Grignon, 289 p. En ligne : https://tel.archivesouvertes.fr/pastel-00000788/

Halliwell B. 2006. Reactive species and antioxidants. Redox biology is a fundamental theme of aerobic life. Plant Physiol., 141: 312-322. DOI: https://doi.org/10.1104/pp.106.077073

Imorou L, Ahoton EL, Zoumarou-Wallis N, Kanlindogbe C. 2018. Water stress effect on agro-morphological and physiological parameters of three local cultivars of maize (Zea mays L.) of South Benin. Int. J. Biol. Chem. Sci., 12(5): 2294-2308. DOI: https://dx.doi.org/10.4314/ijbcs.v12i5.2 9

IPCC (Intergovernmental Panel on Climate Change). 2007. Fourth Assessment Report: synthesis. Published online 17 November 2007 , www.ipcc.ch/pccreports/ar4-syr.htm.

Jia Y, Tanga S, Wang R, Xuehai JX, Yongzhen DY. 2010. Effects of elevated $\mathrm{CO}$ on growth, photosynthesis, elemental composition, antioxidant level and phytochelatin concentration in Lolium mutiforum and Lolium perenne under Cd stress. J. Hazard. Mater., 180. 384-394.

DOI:10.1016/j.jhazmat.2010.04.043

Jones MM, Osmond CB, Turner NC. 1980. Accumulation of solutes in leaves of sorghum and sunflower in response to water deficits. Aust. J. Plant Physiol., 7: 193-205.

DOI: https://doi.org/10.1071/PP9800193

Kavi Kishor PB, Sangam S, Amrutha RN, Sri Laxmi P, Naidu KR, Rao KRSS, Rao S, Reddy KJ, Theriappan P, Sreenivasulu N. 2005. Regulation of proline 
biosynthesis, degradation, uptake and transport in higher plants: Its implications in plant growth and abiotic stress tolerance. Curr. Sci., 88 (3): 424438.

https://www.jstor.org/stable/24110209

Laxa M, Liebthal M, Telman W, Chibani K, Dietz K-J. 2019. The Role of the Plant Antioxidant System in Drought Tolerance. Antioxidants, 8(94). DOI:10.3390/antiox8040094

Lemou F. 2008. Le dérèglement pluviométrique et la dynamique de l'occupation et l'exploitation des sols dans le bassin versant de la Kara (NordTogo). Mémoire de DEA, Université de Lomé, p. 102.

Loka DA, Oosterhuis DM, Ritchie GL. 2011. Water-deficit stress in cotton. In: Stress Physiology in Cotton. Ed. Oosterhuis D.M., 37-72.

Meksem L. 2007. Etude des effets de deux fongicides: Le Flammenco SC et le Tilt 250 EC sur la physiologie, la croissance et le métabolisme énergétique des racines isolées de Triticum durum. DESF, p. 162.

Meskelu E, Mohammed M, Hordofa T. 2014. Response of Maize (Zea mays L.) for Moisture Stress Condition at Different Growth Stages. Int. J. Rec. Res. Life Sci., 1(1): 12-21.

Molinari HBC, Marur CJ, Daros E, De Campos MKF, De Carvalho JFRP, Joa Carlos Bespalhok Filho JCB, Pereira LFP, Vieira LGE. 2007. Evaluation of the stress-inducible production of proline in transgenic sugarcane (Saccharum spp.): osmotic adjustment, chlorophyll fluorescence and oxidative stress. Plant Physiol., 130: $218-229 . \quad$ DOI: https://doi.org/10.1111/j.13993054.2007.00909.x

Ouiza DZ, Belkhodja M, Bissati S, Hadjadj S. 2010. Effet du stress salin sur l'accumulation de proline chez deux espèces d'Atriplex halimus L. et Atriplex canescens (Pursh) Nutt. Eur. J. Sci. Res., 41(2): 249-260.

Parida AK, Das AB, Mohanty P. 2004. Defense potentials to $\mathrm{NaCl}$ in a mangrove, Bruguiera parviflora: differential changes of isoforms of some antioxidative enzymes. $J$. Plant Physiol., 161: 531-542. DOI: https://doi.org/10.1078/0176-161701084

Sandhya V, Ali SKZ, Grover M, Reddy G, Venkateswaralu B. 2010. Effect of plant growth promoting Pseudomonas spp. on compatible solutes antioxidantstatus and plant growth of maize under drought stress. Plant Growth Regul., 62: 21-30. DOI: 10.1007/s10725-010-9479-4

Shigeoka S, Yukinori Y, Takashi M, Kazuya Y, Toru T, Takahiro I. 2002. Activities of amine oxidase, peroxydase and catalase in seedlings of Pisum sativum L. under different light conditions. Plant J., 32(6): 915-925.

Sofo A, Scopa A, Nuzzaci M, Vitti A. 2015. Ascorbate Peroxidase and Catalase Activities and Their Genetic Regulation in Plants Subjected to Drought and Salinity Stresses. Int. J. Mol. Sci., 16: 13561-13578.

DOI: 10.3390/ijms 160613561

Some PP, Hien E, Tozo K, Zombre G, Dianou D. 2010. Effets de six composts sur les réponses physiologiques, biochimiques et agronomiques du niébé Vigna unguiculata L. Walp var. KVX. 61.1. au déficit hydrique. Int. J. Biol. Chem. Sci., 8: 31-45. DOI: http://dx.doi.org/10.4314/ijbcs.v8i1.4

Tartoura KAH. 2010. Alleviation of oxidative stress induced by drought trough application of compost in wheat (Triticum aestivum L.) plants. American-Eurasian J. Agric. Envir. Sci., 9(2): 208-216.

Valentinuz OR, Tollenaar M. 2004. Vertical Profile of Leaf Senescence during the Grain-Filling Period in Older and Newer Maize Hybrids. Crop Sci., 44: 827-834.

Verma S, Sharma A, Kumar R, Kaur C, Arora A, Shah R, Nain L. 2014. Improvement of antioxidant and defense properties of Tomato (var. Pusa Rohini) by application of bioaugmented compost. Saudi J. Biol. Sci.., 22: 256264.

DOI: http://dx.doi.org/10.1016/j.sjbs.2014.11. 003 